\title{
EXTRA-RENAL AZOTAMIA.
}

\author{
$B y$ C. G. BARNES, M.D., B.S., M.R.C.P., (Lond.) \\ (Second Assistant, Medical Unit, St. Mary's Hospital). \\ and T. E. LOWE, M.D., (Melb.) M.R.C.P., (Lond.) \\ (Late Medical Registrar, St. Mary's Hospital)
}

The term 'extra-renal azotæmia' is used in this paper to mean an increase in the non-protein nitrogen of the blood in the absence of organic renal disease. This syndrome may occur in the course of many diseases which otherwise do not appear to be related to one another, and it has therefore attracted considerable attention of recent years, the French and German literature in particular containing many case reports and discussions on the subject.

In this country, although extra-renal azotæmia has been recognized as a complication of high intestinal obstruction since Tileston and Confort ${ }^{(1)}$ drew attention to it in I9I4, and more recently as the result of intensive alkali therapy of peptic ulcer ${ }^{(2,3,4)}$, its occurrence apart from these states has attracted but scanty attention. The object of this paper is to review the clinical conditions in which the syndrome may occur, and to discuss briefly the mechanism of its production with particular reference to diagnosis and treatment.

Although it is doubtful whether the retention of non-protein nitrogen in the blood is of itself detrimental to the organism, the recognition of extra-renal azotæmia is of considerable importance for two reasons :-

In the first place it is a sign of an alteration in the chemical constituents of the blood, due either to pathological changes in cellular activity, or to abnormal water or mineral metabolism. When recognized, therefore, it demands treatment and is of prognostic importance.

Secondly, it may be confused with the azotæmia of gross renal disease, and the appropriate treatment neglected with fatal results.

\section{Etiology.}

As early as I9I2 Nobecourt( ${ }^{(5)}$ and his colleagues recorded a number of cases of diarrhœa and vomiting in infants, in whom the urea content of the cerebro-spinal fluid rose to high levels. Post-mortem examination revealed no definite changes in the kidneys. In IgI4 Tileston and Confort ${ }^{(1)}$ showed that in patients with intestinal obstruction an increase in the blood urea was a common finding, an observation that received support two years later from the experimental and clinical reports of Cooke, Rodenbaugh and Whipple ${ }^{(6)}$; the kidneys appeared normal at examination post mortem. In I923 Porges, Essen and Kander ${ }^{(7)}$ reported that intestinal obstruction with vomiting was associated with a diminution in the chloride content of the plasma, whilst in the following year Lemierre ${ }^{(8)}$ and his colleagues recorded a fatal case of azotæmia in which the kidneys were normal.

These clinical observations were supported by the experimental work of Haden and $\mathrm{Orr}^{(9)}$, who produced high intestinal obstruction in dogs and monkeys by ligaturing the jejunum; they found that after prolonged vomiting the animals developed azotæmia, hypochloræmia, and an alkalosis. Their work was confirmed by that of Binet ${ }^{(10)}$ and of Van Caulaert and Manguio(11), who found the same changes in the blood of animals in which repeated vomiting had been induced by apomorphine. 
The attention of clinicians having thus been drawn to extra-renal azotæmia, it was not long before the syndrome was recognized in the course of many other diseases. These conditions can be grouped simply as follows:-

A. Long-continued loss of body fluids.

(a) Pyloric or high intestinal obstruction ${ }^{(1)}$, or vomiting from other causes including intensive alkali therapy for peptic ulcer ${ }^{(2,3,4)}$.

(b) Diarrhœa from whatever cause, for example, typhoid fever, cholera, the dysenteries, and even prolonged abuse of laxatives ${ }^{(12)}$.

(c) Continuous gastric lavage.

(d) Copious sweating ${ }^{(13)}$.

B. Acute febrile conditions.

(a) Lobar pneumonia ${ }^{(14)}$.

(b) Weil's disease.

(c) Many other acute fevers, including those mentioned above in group A (b).

C. Addison's disease.

D. Extreme arterial hypotension.

(a) Diabetic coma ${ }^{(15)}$.

(b) Following coronary artery occlusion.

E. Severe hepatic failure.

(a) Cirrhosis of the liver ${ }^{(16)}$.

(b) Acute yellow atrophy of the liver ${ }^{(1)}$.

F. Certain nervous disorders. ${ }^{(17) .}$

(a) Encephalitis and meningitis.

(b) Korsakow's psychosis.

As extra-renal azotæmia does not occur until the late stages of many of the above conditions, and in some is extremely rare, its appearance is often of grave significance.

\section{Clinical Picture.}

It is doubtful whether azotæmia of itself gives rise to any symptoms except possibly the drowsiness and disorientation that mark the terminal stages, and the clinical picture of azotæmia must therefore be that of the causal condition. A consideration of the conditions set out above shows that the symptoms will most often be those of dehydration with loss of sodium chloride, and under such conditions a typical picture can be recognized.

After a period during which loss of fluid and sodium chloride from various causes has been depleting the body's reserves, the patient shows signs of dehydration. The eyes are sunken, and there is an easily detected drop in the intra-ocular tension which is itself a manifestation of the low arterial blood pressure. The skin appears dry and loses its normal elasticity, while the pulse becomes thin and rapid. Muscular cramps may occur and cause the patient much distress, and under certain conditions they may be the outstanding symptom, e.g., in stoker's cramps. 
The alkali reserve is raised, except in those cases where abnormal products of metabolism are produced in excessive amounts (as in acute febrile conditions and diabetic coma); this alkalosis is responsible for the shallow breathing that is part of the picture, and may be of sufficient severity to cause latent or manifest tetany.

An examination of the urine shows usually that it is alkaline to litmus, but under certain conditions it may become acid for the reasons set out below. There is a trace of protein, and granular or hyaline casts in moderate numbers, although occasionally cylindruria is absent. The volume of the urine may be reduced, and in that case the specific gravity and the urea concentration are not as high as the oliguria would lead one to expect. A striking feature is the low concentration of chlorides in the urine, which is of diagnostic importance, as has been emphasized by Wohl and Brust, Mozer and Mach ${ }^{(18,19)}$, and others.

An examination of the blood reveals a rise in the non-protein nitrogen, an increase too great to be caused solely by the concentration of the blood, whilst the chloride content of both cells and plasma is diminished. The dehydration may lead to a relative polycythæmia.

In the absence of adequate treatment the condition progresses until the patient becomes drowsy and disorientated and death occurs in coma.

The cause of death in these patients is as obscure as it is in uræmia from renal failure, but does not seem to be related directly to the level of the blood nitrogen or chloride, although these are definitely of prognostic significance.

\section{Recognition of the Condition.}

Extra-renal azotæmia should be suspected when, in the course of any acute illness, an azotæmia develops and increases rapidly until the blood urea or total non-protein nitrogen reaches a high level, especially if the urinary findings are not consistent with a gross disorder of renal function and there is no history of nephritis.

Confirmation is forthcoming if there be a diminution in the urinary chlorides. This can be determined rapidly and simply by adding a $3 \%$ solution of silver nitrate to an equal volume of the urine acidified with concentrated nitric acid. The chlorides will come down as silver chloride forming a yellowish-white curdy precipitate. This precipitate can be compared with that obtained by repeating the test on a sample of normal urine of approximately the same specific gravity. The level of the chlorides of the urine is a rough guide to that of the blood, and the test will not therefore be of assistance in those unusual cases of extra-renal azotæmia in which the chloride of the blood remains normal.

Further points of differentiation between this azotæmia and that of nephritis are that the blood pressure is not raised and that the alkali reserve is usually increased-the reverse of the findings in nephritic cases-while ophthalmoscopically there are no signs of renal retinitis.

\section{Mechanism of Production.}

A number of theories to explain the development of extra-renal azotæmia have been put forward by various writers, and these will now be briefly discussed. Although to us none of them is entirely satisfactory owing to conflicting clinical and experimental evidence, they have nevertheless led to a method of treatment which in practice has proved extremely successful. 
A. Dehydration. It might be supposed that dehydration alone, in virtue of the associated oliguria, would lead to an increase in the non-protein nitrogen of the $\stackrel{\odot}{\circ}$ blood. This increase would be due to the inability of the kidney, in the limited volume of urine available, to excrete sufficient nitrogen to keep pace with its formation in the body. When the breakdown of protein is much increased, as in acute fevers, the resultant azotæmia will be correspondingly greater.

Fishberg ${ }^{(20)}$ finds in this mechanism the main explanation for the azotæmia associated with fluid loss, and experiments on animals seem to support this view. Against this simple explanation, however, is the evidence of Underwood and his colleagues ${ }^{(21)}$. They found that in the gross pulmonary œdema of war-gas poisoning, and in a number of cases of extensive superficial burns, there was no rise of blood urea, although there was a concentration of the blood and hypochloræmia. Further, Rachmilewitz ${ }^{(32)}$ concluded from a study of his cases that the oliguria alone could not explain the azotæmia.

B. Changes in the osmotic pressure of the plasma. The theory that has attracted most attention from clinicians to explain the development of extra-renal azotæmia, is that non-protein nitrogen is retained in the blood to compensate for loss of sodium and chloride ions from the plasma. This suggestion was put forward by Hartmann and Smythe ${ }^{(23)}$, and received the support of Blum ${ }^{(24)}$, who referred to such azotæmia as "azotémie par manque de sel".

Loss of chlorides from the plasma, either as hydrochloric acid from repeated vomiting, or as sodium chloride, is supposed to lead to an increase in the nitrogen of the blood in the following manner. The loss of such an electrolyte from the plasma must lead to a fall in the osmotic pressure of the plasma unless there be corresponding diminution in blood volume. (Such a fall occurs also in Addison's disease when sodium salts are lost even in the absence of vomiting, possibly owing to a lowering of the renal threshold for sodium salts. Frequently sodium and chloride ions will be lost together, as in sweating, and the osmotic pressure of the plasma will fall if the fluid which has been lost be replaced by pure water).

In order that the osmotic pressure of the plasma may be maintained at its physiological level, there must be a higher concentration of the remaining electrolytes in the plasma. Loss of chloride is at first balanced by retention of bicarbonate, but if this be insufficient, urea, which is easily mobilized, is held back in the blood and azotæmia results. Loss of sodium ions is probably a more important cause of retention of urea than is the loss of chloride ions.

Should compensation still be incomplete in spite of urea and bicarbonate retention, sodium and potassium ions are also held back in the blood and are no longer available to act as basic radicles in the urine. Their place is taken by the weaker base ammonium hydroxide, and so the $\mathrm{pH}$ of the urine falls, and it may become acid to litmus in spite of the alkalosis of the blood ${ }^{(23,25)}$.

Hartmann and Smythe attempted to show quantitatively that in their cases the retention of non-protein nitrogen, from the standpoint of osmotic pressure, made up for the deficiency of total electrolyte caused by the failure of the increased bicarbonate ions to balance the loss of chloride ions. They came to the conslusion that on the whole their results lent support to their theory.

The most important point in favour of such a theory, however, is the remarkable way in which the patients react to the administration of sodium chloride. Clinically they improve rapidly, and within a few days the non-protein nitrogen of the blood has fallen and lies once more within normal limits. 
There are a number of theoretical and practical objections which can be brought forward against this theory.

In the first place there is no known mechanism in the kidney by which, if the osmotic pressure of the plasma falls from loss of chlorides, the remaining crystalloids are retained in order to keep the osmotic pressure constant. Further, urea does not greatly raise the osmotic pressure of the plasma, and being readily diffusible, such effect as it might have would only be transitory.

Secondly, many workers have observed that the degree of azotæmia does not run pari passu with the degree of hypochloræmia, and in these cases it does not appear as if the urea was being retained solely for osmotic purposes.

Finally, Thiers ${ }^{(28)}$ has reported several cases in which marked hypochloræmia occurred without a subsequent azotæmia, and there are on record also cases in which repeated tapping of ascitic fluid ${ }^{(29)}$, or a salt-secreting papilloma of the gallbladder ${ }^{(30)}$, have reduced the chloride content of the blood, and azotæmia has not developed.

C. Alkalosis. In view of the fact that cases have been described in which alkalosis and azotæmia have occurred during the treatment of peptic ulcer with large doses of alkali, without loss of chloride from vomiting, the question arises whether alkalosis by itself can cause azotæmia.

In six such cases described by Venables ${ }^{(31)}$ the chloride of the blood was not estimated, but in one of the cases reported by Cooke $^{(4)}$ there was hypochloræmia despite the absence of vomiting.

It is possible that the azotæmia in such circumstances is caused by the diminution of the chloride in the blood; this may be brought about by an increased secretion of hydrochloric acid into the stomach. This increased secretion of acid is well known to follow the administration of certain alkalis, particularly sodium bicarbonate, and will cause a diminution in the chloride of the blood even though vomiting be absent. Azotæmia would then follow for the reasons already discussed. Such an explanation is supported by the experimental work of Gamble ${ }^{(32)}$. He showed that hypochloræmia can occur in rabbits in the absence of vomiting, after the pylorus had been tied, owing to the outpouring of hydrochloric acid into the stomach. In the treatment of peptic ulcer, however, one would expect the excess of alkali used to be more than adequate to compensate for the lowering of osmotic pressure coincident on the loss of chloride, and so azotæmia would not occur.

Cooke $e^{(4)}$ puts forward the view, which is supported by experimental and clinical evidence, that alkalosis per se produces a functional disability of the kidneys. This may be responsible for the retention of non-protein nitrogen. Inability of the kidney to remove the excess of alkali allows the alkalosis to increase, and a vicious circle is set up in this way. By this method of treatment there is also an increased breakdown of protein and this possibly accelerates the development of azotæmia.

This view is the more satisfactory to us because it provides an explanation of one point in the ætiology that is most striking. This is that the patients, in whom azotæmia is most likely to occur during intensive alkali therapy, are those who develop stubborn constipation as a result either of the diet or of the alkaline powders that are given, or both. This condition of constipation might be expected to delay the excretion of alkalis given by the mouth, and in that way the increased alkalosis and the azotæmia would be satisfactorily explained. 
If this theory be correct, it suggests that treatment with massive doses of alkalis is to be avoided in those patients who before treatment show evidence of organic renal disease.

D. Transitory renal failure. There is considerable evidence to suggest that in all cases of extra-renal azotæmia there is inadequate renal function without a structural change of corresponding severity. Mellinghoff ${ }^{(33)}$, for example, showed in his patients with extra-renal azotæmia that the power of the kidney to excrete dye was poor, that the urinary diastatic index fell, whilst the amount of indican in the blood was markedly increased. His work is supported by that of other writers $^{(26,34)}$ who showed that in similar cases there was an increase of indican in the blood, and a poor urea concentration and dye excretion by the kidney.

Further post-mortem studies in fatal cases have often revealed a mild degree of degenerative change in the renal tubules, although the glomeruli were normal ${ }^{(17,26,34)}$. On the other hand, Whipple ${ }^{(6)}$ could find no definite changes post mortem in a series of patients with intestinal obstruction, and Evans ${ }^{(35)}$ has also reported a case in which the kidneys were normal. Valera-Fuentes and Rubino ${ }^{(36)}$ conclude from a critical survey of the literature and from their own cases that this renal factor if present is only of minor importance.

If this theory of functional inefficiency of the kidneys be admitted in extrarenal azotæmia, then grave consequences might be expected were the syndrome to be superimposed for any reason on a kidney already inefficient, e.g., in true nephritis.

Another factor which may play a part in this transitory renal failure is the lowering of the arterial blood pressure upon which is dependent filtration througle the glomeruli. In a case reported by Evans ${ }^{(35)}$ in which the systolic blood pressure fell to $50 \mathrm{~mm} . \mathrm{Hg}$., anuria ensued, but post mortem there was no change in the kidneys. This lowering of blood pressure may play a part in the azotæmia associated with diabetic coma, coronary artery occlusion or Addison's disease.

It seems that in extra-renal azotæmia slight pathological changes may occur in the kidneys and be manifested by albuminuria, cylindruria, and an inability to concentrate urea in the urine to the normal level. When such changes occur they are not the cause of the azotæmia, but are in all probability secondary to changes in the composition of the blood circulating through the kidneys.

An exception to this statement is the azotæmia which follows massive doses of alkalis. Here probably the functional disability of the kidneys due to the changes in the blood is the main cause of the nitrogen retention.

E. Hepatic inefficiency. As the liver is the main site of urea formation in the body, it might be expected that variations in the nitrogen content of the blood would follow liver disorders. Whilst it is well known that the blood urea rises o in Weil's disease, and in other acute pathological conditions of the liver ${ }^{(36)}$, it is $N$ likely that in these circumstances the increase is the result of the loss of water and of sodium and chloride ions on account of diarrhœea and vomiting, and of $\omega$ increased breakdown of protein, rather than of hepatic inefficiency. This is shown by the fact that in these conditions the blood urea rises in proportion to the residual nitrogen; this would not occur were the liver not functioning adequately.

In such conditions as cirrhosis of the liver there may also be a rise in the non-protein nitrogen of the blood, but on analysis the increase is of the residual nitrogen rather than of the urea nitrogen. This type of azotæmia is thus in con- 
trast to that of the other diseases that have been considered, where the increase in the non-protein nitrogen affects the urea moiety in an equal or greater degree than the residual nitrogen.

F. Nervous control. Recently Courtois ${ }^{(17)}$ has produced clinical evidence, for which he quotes experimental support, pointing to a central nervous mechanism in control of nitrogen metabolism. Such a centre is possibly situated in the subthalamic region of the brain, and damage to this centre may be responsible for the azotæmia of such disorders as encephalitis, meningitis, and Korsakow's psychosis. His paper suggests an analogy with the nervous control of water, fat and carbohydrate metabolism.

Courtois himself points out that in many of his patients there was a great increase in tissue breakdown, although there was no hypochloræmia, and this might be responsible to some extent for the azotæmia.

After a consideration of these possible mechanisms for the production of extrarenal azotæmia we feel that none of them is entirely satisfactory. There is no doubt that azotæmia often occurs in those diseases where loss of water or sodium chloride is a marked feature, or where there is excessive breakdown of protein or a low arterial blood pressure. But the evidence to show that these factors are responsible for the azotæmia seems to us at present to be inconclusive, although in each individual condition more than one factor might be implicated. Thus in Addison's disease low blood pressure, loss of sodium chloride, and loss of water all might play a part, whilst in pneumonia loss of chloride and water and increased protein breakdown are all present. In severe cases it seems likely that a functional renal failure may be added, and that this perhaps increases the retention of nitrogen.

\section{Treatment.}

r. To those who consider that the loss of water and sodium chloride from the blood provides a logical explanation for the development of extra-renal azotæmia, the method of treatment is obvious and has long been practised.

It consists in the administraton of normal saline solution, preferably intravenously, or else by some other route. We can see no indication for adding glucose to the saline except in those cases of azotæmia due to severe liver damage. The saline may conveniently be given intravenously by the drip method when large volumes are required by the patient.

It is impossible to deny the efficiency of this treatment, whether or not one considers it to be logical, and there can be no doubt that it has saved the lives of many patients.

Obviously treatment must be directed also to the underlying cause of the azotæmia, such as diabetes, acute febrile conditions, coronary artery thrombosis, or Addison's disease.

2. In acute cases the grave depletion of salt from the body may demand the immediate intravenous injection of hypertonic saline solution, and Mellinghoff ${ }^{(33)}$ has shewn that in these cases the body may retain large quantities of sodium chloride (as much as Ioo grammes) without an increased excretion of chloride in the urine. 
In regard to this method of treatment Frank ${ }^{(37)}$ has issued a word of warning ; if sufficient water be not given by other routes while the hypertonic saline is being administered intravenously there is a grave risk of causing further dehydration of the tissues.

Further, Chabanier ${ }^{(38)}$ maintains that hyperchloræmia itself can embarrass cellular function. When cases are being treated by this method, we therefore think it advisable that administration of sodium chloride should be controlled by regular estimations of the chloride content of the plasma-an estimation that presents little technical difficulty.

3. The close relationship between hypochloræmia and azotæmia suggests that the use of a salt-free diet in the treatment of œdema of nephritic origin is not entirely free from risk. By such treatment an extra-renal azotæmia may be superimposed upon an azotæmia of renal origin, causing further embarrassment to the patient and confusing prognosis.

4. Another point of importance arises in the treatment of patients with peptic ulceration with massive doses of alkalis. It is essential that constipation should not develop in these patients, for otherwise the removal of alkalis from the body will be hindered, and functional renal failure will develop with azotæmia.

5. Finally, continuous gastric lavage is still practised in the treatment of repeated vomiting or gastric dilatation. Such a measure leads to considerableg loss of chlorides from the body and, if the risk of azotæmia is to be avoided, this loss must be counteracted by giving sodium chloride by other routes, a practical point that has recently been emphasized by Katsch ${ }^{(39)}$.

\section{REFERENCES.}

(1) Tileston and Confort. Arch. Int. Med., 1914, xiv, 620.

(2) Ryle, Lancet, 1935, 1, 198

(3) Oakley, ibid., 1935, ii, 187.

(4) Cooke, Quart. Journ. Med., 1932, 1, 527

(5) Nobecourt, Bidot, and Maillet, Buli. et Mem. Soc. méd. d. Hop Paris, 1912, 47.

(6) Whipple, Rodenbaugh, and Cook, Journ. Exp. Med., 1916, xxili, 717.

(7) Essen, Kanders and Porges, Wien. Arch. f. Inn. Med., 1923, V, 499. Paris, 1924 xlvili, 861.

(8) Lemierre, Deschamps and Bernard, Bull. et Mem. Soc. med. d. Hop. Paris, 1924.

(10) Binet, Rev. de Path. Comp., 1927, 142 .

(11) Van Caulaert and Manguio, O.R. de la Boc. de. Biol., 1929, civ, 396.

(12) Merklen, Gounelle, and Adnot, Bull. et Mem. Boc. med. d. Hôp. Paris, 1934, 1, 1332.

(13) McCance, Lancet, 1936, ccxxx, 704.

(14) Haden, Amer. Journ. Med. Scl., 1927, clxxiv, 744.

(15) Iyall and Anderson, Quart. Journ. Med., 1932, i, 353.

(16) Nonnenbruch, Med. Welt., 1934, vili, 1535.

(17) Courtois Presse Mèd. 1934, xlii, 1155 .

(18) Wohl and Brust, Journ. Lab. and Clin. Med., 1935, xx, 1170

(19) Mozer and Mach, Bull. et Mem. Soc. méd. d. Hôp. Paris, 1934, x, 443.

(20) Fishberg, 'Hypertension and nephritis', 1934, 3rd edt.

(21) Underhil, Carrington, Kapsinow, and Pack, Arch. Int. Med., 1923, xxxi1, 31

(22) Rachmilewitz, Lancet, 1934, 1, 78.

(23) Hartmann and Smythe, Amer. Jour. Dis. Ohild., 1926, exxii, (1) 1.

(24) Blum and Van Caulaert, 'Le role du sel dans les nephrites', 1931, edt., p. 175.

(25) Maizels, Univ. Coll. Hosp. Magaz., 1936, xxi, (1) 5.

(26) Verspijck and Maathius, Nederl. tijdschr. v. geneesk,

(28) Merklen and Counelle, Progres. med., 1934, xli1, 1155 .

(29) Mach, Mach, and Sciclounoff, Schweiz. med. Wchnschr., 1934, 1xiv, 54

(30) Kerr and Lendrum, Brit. Journ. Surg., 1935-6, xxill, 615.

(31) Venables, Guy's Hospital Reports, 1925, series 4, v 153.

(32) Gamble. Proc. Soc Exp. Biol. and Med., 1924-5, xxi1, 365.

(33) Mellinghoff Deut Med Woch 1934 1x, pt. $2,1127$.

(34) Mellnghofi, Deut. Med. Hartmann, and Rowntree, Arch. Int. Med., 1923, xxxi1, 425.

(35) Brown, Eustermann, Tart 1bid. 1931, xlvili, 1231 .

(36) Evans, 1bid., 1931, xlvili, 1231.

(37) Frank, Med. Klin., 1932, xli1

(38) Chabanier and Lobo-Onell, 'Exploration fonctionelle des reins,' 1930, edt., 92.

(39) Katsch, Klin. Woch., 1933, xil, 989. 